\title{
PERANAN PEMERINTAH DALAM PENYELESAIAN SENGKETA PELARANGAN UPACARA KEMATIAN DI SETRA BANJAR YANGAPI
}

\author{
Oleh : \\ Ni Made Ariswandani ${ }^{1}$
}

\begin{abstract}
Abstrak
The dispute of death ceremony disallowance in Setra Banjar Yangapi is a dispute arising from the imposition of Kasepekang customary sanction against villagers who are considered to have committed adat violations. The dispute arose from the commencement of process of expansion of Dalem Yangapi Pakraman Village. The aim of this research is to find out the effect caused by the implementation of one of Balinese customary sanction and its relevance to national law and local government efforts in resolving the dispute by maintaining the tranquility of the village members. At mediation level on dispute settlement pursuant to the Regional Regulation of Bali Province No. 6 of 1986 on the Standing, Functions and Roles of Indigenous Villages as a Unity of Customary Law Community in the Level I Territory of Bali Province, it is not clearly stipulated in this regulation, it only states that the Governor assisted by MPLA dan BPPLA will become a mediator and then replaced by the Regional Regulation of Bali Province No. 3 of 2001 on Pakraman Village and MDP reserves the right as mediator, but in reality the local government and its staff are mediators in the settlement of adat disputes. The results of this research indicate that the dispute settlement process was initially conducted through mediation proceedings, but because mediation did not succeed, one party chose to perform the death ceremony by cremation while maintaining and without reducing the meaning of ceremony performed by the village members.
\end{abstract}

Keywords: The role government, Death ceremony disallowance.

\begin{abstract}
Abstrak
Sengketa pelarangan upacara kematian di Setra Banjar Yangapi merupakan sengketa yang timbul sebagai akibat diterapkannya sanksi adat kasepekang terhadap warga desa yang dianggap melakukan pelanggaran adat. Sengketa tersebut muncul sejak dimulainya proses pemekaran Desa Pakraman Dalem Yangapi. Tujuan penelitian ini adalah untuk mengetahui akibat yang ditimbulkan penerapan salah satu sanksi adat Bali serta relevansi nya terhadap hukum nasional dan upaya-upaya pemerintah daerah dalam menyelesaikan sengketa adat dengan berusaha tetap menjaga ketentraman warga desa. Pada tingkat mediasi penyelesaian sengketa berdasarkan Peraturan Daerah Propinsi Bali Nomor 6 Tahun 1986 tentang Kedudukan, Fungsi dan Peranan Desa Adat sebagai Kesatuan Masyarakat Hukum Adat Dalam Propinsi Daerah Tingkat I Bali pada peraturan ini tidak disebutkan secara jelas hanya menyebutkan Gubernur dibantu oleh
\end{abstract}

1 Lawyer kantor Bali Tri Semaya, Denpasar, Bali, e-mail : made_swandani@yahoo.com 
MPLA dan BPPLA yang menjadi mediator kemudian diganti dengan Peraturan Daerah Propinsi Bali Nomor 3 Tahun 2001 tentang desa pakraman dan MDP yang memiliki hak sebagai mediator, tetapi pada kenyataannya pemerintah daerah beserta jajarannya yang menjadi mediator dalam penyelesaian sengketa adat. Hasil penelitian ini menunjukkan bahwa proses penyelesaian sengketa pada awalnya dilakukan melalui proses mediasi, tetapi karena mediasi tidak berhasil maka salah satu pihak memilih untuk melakukan upacara kematian dengan melalui kremasi dengan tetap tidak mengurangi makna suatu upacara yang dilaksanakan oleh warga desa.

Kata kunci: peranan pemerintah, pelarangan upacara kematian.

\section{PENDAHULUAN}

Bali merupakan salah satu tempat tujuan utama para wisatawan baik internasional maupun lokal. Bali dikenal tidak hanya dari keindahan alamnya tetapi dari kesenian dan kebudayaannya. Salah satu kebudayaan Bali yang unik adalah upacara kematian yang lebih dikenal dengan sebutan ngaben. Masyarakat umum mengenal ngaben merupakan upacara pembakaran mayat di mana pelaksanaannya melibatkan seluruh masyarakat desa. Ngaben adalah sebutan lain Palebon yang memiliki arti menjadikan prathiwi (abu) untuk menjadikan tanah. Terdapat dua cara palebon yaitu dengan cara membakar dan dengan cara menanam ke dalam tanah. $^{2}$

Pada beberapa tahun belakangan ini terjadi beberapa sengketa adat pelarangan upacara kematian di setra (kuburan) milik desa pakraman yang ada di Bali. Pada umumnya sengketa pelarangan upacara kematian

2 I Nyoman Singgin Wikarman, 2002, Ngaben upacara dari tingkat sederhana sampai utama, Paramita, Surabaya. hlm. 16. tersebut merupakan sengketa yang timbul akibat dijatuhkannya sanksi kasepekang kepada warga desa yang melakukan pelanggaran atau warga yang dianggap menentang desa adat. Penjatuhan sanksi-sanksi adat di Bali diatur pada bagian Pamidanda di dalam awig-awig yang merupakan salah satu perwujudan hukum adat Bali. ${ }^{3}$ Peraturan Daerah No 3 Tahun 2001 pasal 1 angka 11 menyebutkan Awig-awig merupakan aturan yang dibuat oleh krama desa pakraman sebagai pedoman dalam pelaksanaan Tri Hita Karana sesuai dengan Desa Mawacara dan Dharma agama di Desa Pakraman/Banjar Pakraman masingmasing. ${ }^{4}$ Adapun tujuan daripada dijatuhkannya saksi kepada warga desa adalah untuk mengembalikan keseimbangan ketiga hubungan yang di sebut Tri Hita Karana yaitu hubungan dengan Tuhan, hubungan dengan sesama dan hubungan

3 I Ketut Sudantra, Wayan P. Windia dan Putu Dyatmikawati, 2011, Penuntun Penyuratan Awig-Awig, Udayana University Press, Denpasar. hlm. 7.

4 I Wayan Surpha, 2006, Seputar Desa Pakraman dan Adat Bali, Pustaka Bali Post, Denpasar, hlm. 260 
dengan lingkungan. Konsep sanksi kasepekang tidak dijelaskan secara rinci dalam awig-awig, melainkan hanya disebutkan sebagai salah satu sanksi adat yang dapat diterapkan pada desa pakraman. Menurut Koti Cantika, pihak yang dijatuhi sanksi kasepekang adalah mereka yang tidak diladeni pelaksanaan kegiatan suka dan duka dengan tidak diberikan informasi, tidak mendapat suara kentongan dan tidak diizinkan ikut dalam pelaksanaan persembahyangan yang dilaksanakan oleh desa adat serta tidak diberikan bantuan gotongan dalam penguburan. Walaupun demikian warga yang mendapatkan sanksi tetap berhak
Penjelasan di atas menegaskan bahwa walaupun seorang warga desa telah dijatuhkan sanksi kasepekang namun sesungguhnya masih memiliki hak untuk menggunakan fasilitas yang ada di desa pakraman seperti kuburan dan pura. Jadi pelarangan upacara kematian di setra tidak ada pengaturannya dalam awig-awig desa pakraman.

Dalam hal warga desa dianggap melakukan pelanggaran, maka melalui paruman desa sanksi adat akan dijatuhkan kepada warga yang melakukan pelanggaran. Adapun jumlah kasus pelarangan penguburan di Bali Tahun 2001-2013 dapat dilihat di bawah ini:

Sengketa Adat Upacara Kematian Desa Pakraman di Bali Tahun 2001-2013

\begin{tabular}{|c|c|c|c|}
\hline No & Kabupaten & Latar belakang Sengketa Adat & Jumlah \\
\hline \multirow[t]{3}{*}{1} & Tabanan & $\begin{array}{l}\text { a. Tanah Setra Desa Pakraman Cekik dengan Desa Pakraman Gablogan } \\
\text { Kecamatan Selemadeg }\end{array}$ & 1 \\
\hline & & b.Pemekaran Desa Pakraman Dalem Yangapi Kecamatan Kediri & 4 \\
\hline & & $\begin{array}{l}\text { c. Pemekaran Banjar Pangkung Karung dari Pakraman Bedha Kecamatan } \\
\text { Kerambitan }\end{array}$ & 1 \\
\hline 2 & Jembrana & - & - \\
\hline 3 & Kota Denpasar & - & - \\
\hline 4 & Bangli & - & - \\
\hline 5 & Karangasem & - & - \\
\hline 6 & Buleleng & - & - \\
\hline 7 & Klungkung & $\begin{array}{l}\text { Perebutan pura dalem, setra dan pura prajepati Desa Kemoning dengan Desa } \\
\text { Budaga Kecamatan Semarapura }\end{array}$ & 1 \\
\hline 8 & Badung & - & - \\
\hline \multirow[t]{4}{*}{9} & Gianyar & $\begin{array}{l}\text { a. Perebutan Pura Khayangan Tiga Desa Pakraman Getas Kawan dengan } \\
\text { desa Pakraman Dharmasanmata Kecamatan Blahbatuh }\end{array}$ & 1 \\
\hline & & $\begin{array}{l}\text { b. Sengketa tanah laba pura Banjar Pakudui Kangin dengan Banjar Pakudui } \\
\text { Kawan Desa Kedisan Kecamatan Tegallalang }\end{array}$ & 1 \\
\hline & & $\begin{array}{l}\text { c. Tidak melakukan kewajiban sebagai warga desa Desa Pejeng Kecamatan } \\
\text { Tampaksiring }\end{array}$ & 1 \\
\hline & & $\begin{array}{l}\text { d. Tidakmelaksanakan kewajiban sebagai warga desa Desa Bukian Kecamatan } \\
\text { Payangan }\end{array}$ & 1 \\
\hline
\end{tabular}

Sumber: Majelis Madya Kabupaten Tabanan, Majelis Madya Kabupaten Jembrana, Majelis Madya Kabupaten Kabupaten Kota Denpasar, Majelis Madya Kabupaten Bangli, Majelis Madya Karangasem, Majelis Madya Buleleng, Majelis Madya Klungkung, Majelis Madya Gianyar dan Majelis Madya Badung pada tanggal 23 November 2016.

untuk melaksanakan persembahyangan di pura serta melakukan upacara penguburan di kuburan (setra) milik desa, tetapi tanpa adanya bantuan dari warga desa adat yang lain. ${ }^{5}$ 5 Anak Agung Istri Ari Atu Dewi, 2010,
Eksistensi Sanksi Adat Kasepekang Dalam Awig-Awig Dalam Kaitan Dengan Penjatuhan Sanksi Adat Kasepekang di Desa Pakraman, Kerta Patrika Jurnal Ilmiah Fakultas Hukum Universitas Udayana, Vol. 34 No 1 Edisi Januari 2010, hlm. 52 
Berdasarkan tabel di atas dapat dijelaskan bahwa jumlah terbanyak sengketa upacara kematian terjadi di wilayah Kabupaten Tabanan yaitu terdapat 6 sengketa sedangkan Kabupaten Gianyar menjadi urutan yang kedua yaitu terdapat 4 sengketa dan Kabupaten Klungkung hanya terdapat 1 sengketa saja. Jika dilihat dari latar belakang sengketa maka pemekaran Desa Pakraman Dalem Yangapi yang paling banyak menimbulkan sengketa pelarangan upacara kematian yaitu terdapat 4 sengketa, sedangkan sengketa adat yang lainnya hanya menimbulkan satu sengketa saja. Fakta tersebut yang menjadi alasan bahwa penyelesaian sengketa pelarangan upacara kematian tersebut menjadi menarik untuk dikaji.

Penjelasan latar belakang tersebut di atas dapat dibuat suatu rumusan masalah yaitu

1. Apakah pelarangan upacara kematian di setra milik desa pakraman bertentangan dengan ketentuan hukum nasional?

2. Bagaimanakah upaya-upaya pemerintah dalam penyelesaian sengketa pelarangan upacara kematian tersebut?

Beberapa penelitian hukum terkait dengan penyelesaian sengketa adat yang berupa jurnal telah dilakukan beberapa pihak. Pertama, penelitian yang dilaksanakan oleh I Nyoman Adi Susila, I Ketut Wirta Griadhi dan A.A.
Gde Oka Parwata. (2013) ${ }^{6}$ berjudul "Penyelesaian Sengketa Adat di Bali Studi Kasus Sengketa Tanah Setra Antara Desa Pakraman Cekik Dengan Desa Pakraman Gablogan Kecamatan Selemadeg Kabupaten Tabanan". Penelitian ini mengkaji tentang penyelesaian sengketa adat tanah setra. Perbedaannya dengan penelitian penulis adalah penelitian I Nyoman Adi Susila, I Ketut Wirta Griadhi dan A.A. Gde Oka Parwata meneliti tentang penyelesaian sengketa tanah setra yang diselesaikan melalui mediasi dan faktor-faktor yang mempengaruhi penyelesaian sengketa adat tersebut. Penelitian penulis adalah tentang penyelesaian sengketa adat pelarangan upacara kematian di setra. Kedua, Penelitian dilakukan oleh I Made Dedy Priyanto dan kawan-kawan (2012) ${ }^{7}$ yang berjudul "Penyelesaian Sengketa Perebutan Tanah Kuburan (Setra) Desa Pakraman Padang Sambian dan Desa Pakraman Kerobokan”. Penelitian ini mengkaji tentang status tanah kuburan (setra) serta metode penyelesaian 6 INyoman Adi Susila, I Ketut Wirta Griadhi dan A.A. Gde Oka Parwata, 2013, “ Penyelesaian Sengketa Adat di Bali Studi Kasus Sengketa Tanah Setra Antara Desa Pakraman Cekik Dengan Desa Pakraman Gablogan Kecamatan Selemadeg Kabupaten Tabanan", available URL: ojs.unud.ac.id/index.php/Kerthanegara/ article/download/5293/4050.

7 I Made Dedy Priyanto dkk, 2013, "Penyelesaian Sengketa Perebutan Tanah Kuburan (Setra) Desa Pakraman Padang Sambian dan Desa Pakraman Kerobokan", available URL : erepo. unud.ac.id/.../ID1_19840411200812 100320091311949 artikel-format-ideal-penye lesaian-sengketa-perebutan-tanah-kuburanMicrosoft Word. 
sengketa perebutan tanah kuburan. Penelitian yang dilakukan oleh Dedy Priyanto, dkk ini sama sekali tidak menyinggung penyelesaian sengketa pelarangan upacara kematian.

Secara umum tujuan penelitian ini adalah untuk meneliti penyelesaian sengketa pelarangan upacara kematian dalam proses pemekaran Desa Pakraman Dalem Yangapi, sedangkan tujuan khususnya adalah pertama, untuk mengetahui apakah pelarangan upacara kematian ini sesuai atau tidak dengan ketentuan hukum nasional, kedua, untuk mengetahui upayaupaya pemerintah dalam penyelesaian sengketa pelarangan upacara kematian.

\section{METODE PENELITIAN}

Penelitian ini merupakan penelitian hukum empiris (nondoctrinal research) ${ }^{8}$ yang oleh Soerjono Soekanto ${ }^{9}$ disebut penelitian hukum sosiologis. Penelitian ini bersifat deskriptif analitis karena menggambarkan dan mengkaji secara kritis fakta-fakta hukum terkait dengan penyelesaian sengketa pelarangan upacara kematian dalam proses pemekaran Desa Pakraman Dalem Yangapi.

Data yang digunakan dalam penelitian ini adalah data primer dan data sekunder. Data primer diperoleh

8 E. Jones, 1962,Cureent Trends In Legal Research, Expert, Journal of Legal Education, hlm. 37

9 Bambang Sunggono, 2010, Metodologi Penelitian Hukum, Rajagrafindo Persada, Jakarta. hlm 42 dari penelitian lapangan sedangkan data sekunder diperoleh dari penelitian kepustakaan. Teknik pengumpulan data yang digunakan dalam penelitian ini adalah teknik studi dokumen untuk mengumpulkan data sekunder sedangkan untuk pengumpulan data primer dilakukan dengan teknik wawancara.

Lokasi penelitian adalah Banjar Yangapi Desa Adat Klaci Kaja. Adapun alasan dalam menentukan tempat penelitian ini adalah pertama, sengketa pelarangan upacara kematian ini sebagai akibat dari proses pemekaran Desa Pakraman Dalem Yangapi yang sebelumnya merupakan bagian dari Desa Adat Klaci Kaja. Kedua, sengketa pelarangan upacara kematian terjadi lebih dari sekali selama proses pemekaran desa tersebut. Pengolahan serta analisis data primer dan data sekunder menggunakan metode kualitatif.

\section{HASIL DAN PEMBAHASAN}

\subsection{Deskripsi Masalah}

Para pihak yang bersengketa terdiri dari dua kelompok yaitu kelompok besar dan kelompok kecil. Kelompok besar terdiri dari 72 kepala keluarga yang berasal dari warga Banjar Tapesan dan sebagian besar warga Banjar Yangapi sedangkan kelompok kecil terdiri dari 27 kepala keluarga yang berasal dari sebagian kecil warga Banjar Yangapi.

Jika dilihat dari letak wilayah maka dapat dijelaskan bahwa Desa 
Pakraman Dalem Yangapi sebelum memisahkan diri merupakan bagian dari wilayah Banjar Adat Yangapi, dimana Banjar Adat Yangapi termasuk wilayah adat dari DesaAdatKlaci Kaja. Penjelasan di atas dapat digambarkan seperti bagan di bawah ini. menandatanagi surat perjanjian untuk mendukung adat serta mendatangi rumah warga untuk dimintakan persetujuan dengan disertai ancaman.

tanah laba pura dijadikan hutan lindung. Hasil dari hutan tersebut

Banjar Adat di Lingkungan

Desa Adat Klaci Kaja

DESA ADAT KLACI KAJA

BANJAR ADAT

TAPESAN

$\mathrm{A}=130 \mathrm{KK}$

BANJAR ADAT

YANGAPI

KELOD

$\mathrm{C}=45 \mathrm{KK}$

KELOMPOK BESAR

\author{
BANJAR ADAT \\ YANGAPI \\ $\mathrm{B}=72 \mathrm{KK}$
}

\author{
BANJAR ADAT \\ YANGAPI KAJA \\ DIUBAH BANJAR \\ DALEM YANGAPI \\ $\mathrm{D}=27 \mathrm{KK}$
}

Sumber Data : Hasil wawancara dengan I Ketut Sorog tanggal 20 Januari 2016, Data diolah penulis Ket : Kelompok Kecil mekar menjadi Desa Pakraman Dalem Yangapi

Sengketaberawaldaripembuatan awig-awig dan ketika menyinggung masalah status tanah laba Pura Dalem terdapat beda pendapat. Terjadinya perbedaan pendapat antara para pihak menyebabkan kelompok besar bertindak sebagai berikut

- membuat laporan yang ditujukan kepada Lurah Abiantuwung bahwa tanah laba tersebut milik Desa Tri Kahyangan

- $\quad$ rapat yang dilaksanakan dengan cara voting suara dengan akan dijadikan biaya bila terdapat upacara adat di pura dalem oleh kelompok kecil.

Tindakan-tindakan tersebut di atas tidak disetujui olehkelompok kecil. Kasus lain yang muncul berupa upacara pengangkatan pemangku di prajapati, padahal di pura prajapati sudah ada pemangku. Hal ini tidak disetujui oleh kelompok kecil ditunjukkan dengan menghalang-halangi kelompok besar dalam melaksanakan upacara tersebut. Kasus lain adalah tindakan-tindakan 
yang diterima oleh kelompok kecil selama pelaksanaan paruman berupa perlakuan tidak pantas seperti mengusir dari paruman, tidak memberikan menyatakan pendapat, suryak siu (bersorak beramai-ramai) beserta ancaman. Selanjutnya kelompok kecil dijatuhi saksi kasepekang yaitu di larang ke pura, dilarang ikut kegiatan subak dan mendapat perlakuan tidak menyenangkan dalam kehidupan sehari-hari baik itu anak-anak maupun orang dewasa.

Pada tanggal 5 Desember 2000 terjadipengerusakanrumahdanwarung kelompok kecil yang dilakukan oleh kelompok besar. Tanggal 14 Januari 2001 terjadi kesepakatan berpisah, dimana kelompok kecil sementara dinamakan Banjar Yangapi Kaja dan kelompok besar dinamakan Banjar Yangapi Kelod. Hal ini dipertegas dengan kesepakatan persembahyangan bergilir di Pura Balai Banjar Yangapi.

Tanggal 7 Maret 2001 terdapat kesepakatan bersatu kembali. Pihakpihak yang bersengketa memiliki pendapat yang berbeda tentang kesepakatan tersebut yaitu pihak kelompok besar menganggap dengan adanya kesepakatan tersebut kelompok kecil menyetujui segala keinginan dari kelompok besar. Hal tersebut membuat kelompok kecil menyatakan memisahkan diri menjadi Desa Pakraman Dalem Yangapi dan kelompokbesarmenyatakan penolakan atas pemekaran desa tersebut.
Tanggal 7 Januari 2002 terjadi pembakaran terhadap rumah dan pengrusakan serta pembakaran terhadap pura dalem dan pura desa. Pada tanggal 10 Desember 2007 pemekaran desa diakui oleh Majelis Desa Pakraman, wadah tunggal desa pakraman seluruh Bali. Hal itu terbukti dengan adanya putusan Majelis Utama Desa Pakraman (MDP) No. 004/ Kpts/MDP Bali/XII/2007 tentang Pemekaran Desa Pakraman Dalem Yangapi Kecamatan Kediri, Kabupaten Tabanan.

\subsection{Pelarangan Upacara Kematian Bertentangan dengan Hukum Nasional}

Jika dilihat dari hukum adat di Bali pelarangan pengabenan bukan merupakan salah satu sanksi adat Bali, pengaturannya pun tidak ada diatur dalam awig-awig. Pelarangan ngaben timbul akibat penerapan dari sanksi adat kasepekang itu sendiri, dimana menurut I Made Widnyana kasepekang merupakan sanksi yang dijatuhkan kepada warga desa dengan tidak mengajaknya berbicara oleh warga desa yang lain karena dianggap melakukan perbuatan-perbuatan yang melanggar aturan-aturan banjar/ desa. ${ }^{10}$ Jika ditinjau dari Hak Asasi Manusia maka dapat dilihat beberapa ketentuan yang dapat dijadikan landasan hukum untuk menganalisis persoalan ini Pasal 28 E angka (1)

10 I Made Widnyana, 1993, Kapita Selekta Hukum Pidana Adat, PT Eresco, Bandung. hlm 19 
UUD 1945 menyebutkan bahwa setiap orang bebas memeluk agama dan beribadat menurut agamanya, memilih pendidikan dan pengajaran, memilih pekerjaan, memilih kewarganegaraan, memilih tempat tinggal di wilayah Negara dan meninggalkannya serta berhak kembali. Pasal 29 angka (2) UUD 1945 menyebutkan Negara menjamin kemerdekaan tiap-tiap penduduk untuk memeluk agamanya masing-masing dan untuk beribadat menurut agamanya dan kepercayaannya itu. Pada peraturan Undang-Undang No. 39 Tahun 1999 tentang Hak Asasi Manusia Pasal 4 dan Pasal 22 pada intinya menyebutkan setiap orang memiliki hak beragama, bebas memeluk agamanya masingmasing dan untuk beribadat menurut agamanya dan kepercayaannya itu.

Dari peraturan-peraturan tersebut di atas dapat dikatakan bahwa setiap orang memiliki hak untuk memilih keyakinan atau beragama dan melaksanakan ibadah sesuai dengan keyakinannya masing-masing.

Dilihat dari Kitab UndangUndang Hukum Pidana, justru perbuatan melarang atau menghalanghalangi orang lain melakukan kegiatan keagamaan, termasuk upacara kematian merupakan tindak pidana. Pada Kitab Undang-Undang Hukum Pidana Pasal 175 ditentukan bahwa barangsiapa dengan kekerasan atau dengan ancaman kekerasan, merintangi pertemuan agama umum yang diizinkan atau upacara agama yang diizinkan atau upacara penguburan mayat, dipidana dengan pidana penjara selama-lamanya satu tahun empat bulan. Upacara penguburan mayat dalam pasal 175 dapat dijelaskan sebagai berikut :

a) Upacara yang dilaksanakan sewaktu masih ada di rumah

b) Upacara diselenggarakan ketika berada di perjalanan menuju ke makam

c) Maupun upacara yang dilakukan ketika telah berada di makam tempat penguburan.

Selanjutnya pada pasal 178 menyebutkan barangsiapa dengan sengaja merintangi atau menghalanghalangi jalan yang diizinkan untuk masuk ke suatu kuburan atau pembawaan mayat yang diizinkan untuk masuk ke sesuatu kuburan, dipidana dengan pidana penjaraselamalamanya satu bulan dua minggu atau dengan sebanyak -banyaknya seribu delapan ratus rupiah. Pelaku yang melakukan perbuatan ini agar dapat dituntut harus ada unsur kesengajaan. Ada beberapa unsur dari pasal tersebut yaitu

1) Merintangi atau menghalanghalangi dimana perbuatan harus dilakukan dengan sengaja sehingga perjalanan para pengiring dan pengusungan mayat itu sendiri menjadi terhalang dan tidak bisa berlangsung. Hal di atas berbeda dengan menyusahkan, meskipun dengan susah payah, namun dengan perjalanan panjang 
pengiring dan pengusungan jenazah masih dapat dilakukan.

2) Pembawaan mayat tersebut harus tidak dilarang maksudnya bahwa jenazah tersebut itu telah melalui pemeriksaan oleh dokter pemerintah dan kematiannya itu sudah dilaporkan pada pemerintah daerahdiwilayahnya, bukan merupakan kematian diakibatkan oleh kejahatan yang tidak atau belum ditangani oleh pihak yang berwajib atau polisi.

3) Jalan yang digunakan adalah jalan yang diizinkan untuk berlalu-lintas, artinya bukan merupakan jalan melalui pekarangan seseorang.

Apabila merintangi upacara pada saat menuju ke kuburan atau pemakaman dan tidak merusak sarana upacara maka orang itu melanggar pasal 178 dan tidak melanggar pasal 175

Penjelasan aturan - aturan tersebut dapat dikatakan bahwa pelarangan pengabenan merupakan pelanggaran hak asasi manusia karena dianggap menghalangi seseorang melakukan ibadah. Selain itu, tindakan tersebut merupakan pelanggaran pidana.

\subsection{Upaya-upaya Penyelesaian Sengketa Adat Pelarangan Upacara Kematian}

Dalam kasus di Desa Adat Klaci Kajapenjatuhansanksiadatkasepekang dilaksanakanmelaluiparuman desa dan sengketa adat pelarangan pengabenan ditimbulkan akibat sanksi adat tersebut, diselesaikan melalui mediasi. Mediasi merupakan proses damai di mana pihak-pihak yang bersengketa menyerahkan penyelesaiannya kepada pihak mediator. ${ }^{11}$ Menurut Widnyana, terdapat 4 (empat) jenis mediator berdasarkan wewenangnya yaitu ${ }^{12}$

1) Social Network Mediators adalah mediator yang berasal dari orang yang berpengaruh seperti tokoh agama dan tokoh adat dari masyarakat setempat.

2) Authoritative Media-tors merupakan seseorang yang memiliki hubungan wewenang dengan Para pihak dan memiliki jabatan yang lebih tinggi.

3) Independent Mediators merupakan mediator yang sangat umum ditemukan dalam berbagai budaya atau tradisi pada suatu pengadilan independen yang dengan cara yang adil dan yang tidak memihak sebagai pembuat keputusan.

Dalam kasus Yangapi, pihak yang menjadi mediator adalah pemerintah daerah beserta jajarannya, sehingga dapat dikualifikasikan sebagai authoritative mediators. Pengaturan tentang mediasi tidak diatur dengan jelas pada Peraturan Daerah Propinsi

11 I Made Widnyana, 2007, Alternatif Penyelesaian Sengketa (ADR), Jakarta, hlm 107 (dikutip : H. Priyatna Abdurrasyid, 2002, Arbitrase \& Alternatif Penyelesaian Sengketa, PT Fikahati Aneska bekerja sama dengan dengan Badan Arbitrase Nasional Indonesia (BANI), hlm 34)

12 Ibid. hlm 110-111 
Bali Nomor 6 Tahun 1986 tetapi hanya menyebutkan pada Pasal 12 menyebutkan

1. Pembinaan Desa Adat dilakukan oleh Gubernur Kepala Daerah

2. Dalam melaksanakan fungsi sebagai tersebut ayat

Gubernur Kepala Daerah dibantu oleh Majelis Pembina Lembaga Adat (MPLA) dan Badan Pelaksana Pembina Lembaga Adat (BPPLA).

Berdasarkan bahwa Gubernur yang merupakan kepala daerah jika melaksanakan pembinaan maka dibantu oleh MPLA dan BPPLA. Kemudiandigantilahperaturantersebut dengan Peraturan Daerah Nomor 3 Tahun 2001 tentang Desa Pakraman yang diakui menjadi mediator di sini adalah Majelis Desa Pakraman untuk selanjutnya disebut MDP yang merupakan suatu organisasi yang beranggotakan seluruh desa pakraman di Bali. Sedangkan pada kenyataannya dalam proses penyelesaian sengketa yang menjadi mediator adalah pemerintah daerah dimana menurut Undang-Undang Nomor 22 Tahun 1999 tentang Pemerintah Daerah Pasal 1 huruf $b$ menyebutkan pemerintah daerah merupakan Kepala Daerah beserta perangkat Daerah Otonom yang lain sebagai Badan Eksekutif Daerah. Selanjutnya Undang-Undang tersebut diganti dengan UndangUndang Nomor 32 Tahun 2004 tentang Pemerintahan Daerah Pasal 1 angka 3 menyatakan bahwa pemerintah daerah adalah Gubernur, Bupati, atau Walikota, dan perangkat daerah sebagai unsur penyelenggara pemerintah daerah. Berdasarkan hal tersebut di atas menjelaskan bahwa Majelis Desa Pakraman bukan termasuk pemerintah daerah karena itu mediator dalam penyelesaian sengketa ini pemerintah daerah yang disebutkan pada UndangUndang di atas. MDP belum menjadi mediator saat itu dikarenakan MDP baru dibentuk pada tahun 2014 .

Sesungguhnya, aturan mengenai sengketa adat diatur pada Peraturan Daerah Propinsi Bali Nomor 3 Tahun 2001 tentang Desa Pakraman. Pasal 16 angka $1 b$ dinyatakan bahwa Majelis Desa Pakraman mempunyai tugas memberikan saran, usul dan pendapat kepada berbagai pihak baik perorangan, kelompok/lembaga termasuk pemerintah tentang masalahmasalah Adat. Angka 2a menyebutkan Majelis Desa Pakraman mempunyai wewenang memusyawarahkan berbagai hal yang menyangkut masalah-masalah Adat dan agama untuk kepentingan Desa Pakraman. Angka 2b menyebutkan sebagai penengah dalam kasus-kasus Adat yang tidak dapat diselesaikan pada tingkat Desa.

Pada tanggal 7 Maret 2001 untuk pertama kalinya sengketa pelarangan penguburan terjadi yaitu penguburan Ni Wayan Sumerti warga dari Kelompok Kecil. Pelarangan itu dilakukan oleh kelompok besar karena alasannya kelompok kecil sudah 
dibebankan sanksi adat kasepekang oleh desa adat. Jika kelompok kecil ingin melaksanakan pengabenan maka harus membayar penanjung batu sebesar Rp. 5 juta dan biaya penguburan sebesar Rp. 2,5 juta dan kelompok kecil mau meminta maaf dengan muspa (sembahyang) bersama di Pura Kahyangan Klaci Kaja.

Kedua kelompok tersebut sempat berupaya menyelesaikannya melalui mediasi di Kantor Bupati dengan moderator Sekretaris Daerah Tabanan IGM Purnayasa pada Selasa, 6 Maret 2001 tetapi belum ada kesepakatan dan pertemuan direncanakan akan dilanjutkan besok 7 Maret 2001. Pada awalnya rapat direncanakan diadakan di kantor Bupati, ternyata diadakan di Pura Kahyangan Klaci Kaja atas kehendak para pihak yang bersengketa. Pada rapat tersebut turut hadir Bupati Tabanan didampingi Sekretaris Daerah dan Ketua DPRD, Kapolsek Kediri beserta para pihak yang bersengketa. Adapun kesepakatan yang berhasil dibuat adalah yang pertama, kedua pihak secara bersama-sama kembali bersatu sebagai warga adat Desa Adat Klaci Kaja, kedua secara bersamasama saling maaf memaafkan dengan jalan ngaturang upakara guru piduka di Pura Tri Khayangan Desa Adat Klaci Kaja. Kesepakatan ini merupakan penyelesaian dari sengketa pelarangan penguburan tersebut.

Kelompok besar beranggapan bahwa adanya kesepakatan tersebut memiliki arti bahwa kelompok kecil menyetujui bahwa tanah laba pura merupakan milik desa. Hal tersebut menyebabkan timbulnya sengketa kedua pelarangan pengabenan yaitu pengabenan I Made Moglong merupakan salah satu warga dari Kelompok Kecil, dimana sejak malam tanggal 2 Juni 2002 Setra Yangapi telah diduduki oleh massa kelompok besar dengan tujuan untuk menggagalkan atau menghalang-halangi upacara pengabenan tersebut. Kelompok besar sudah mengetahui bahwa akan dilaksanakan upacara pengabenan yang rencananya akan dilaksanakan pada tanggal 5 Juni 2002. Dengan tindakan tersebut kelompok kecil melaporkan kejadian tersebut kepada Gubernur Bali, Kapolda Bali, Bupati Tabanan, DAN RINDAM IX Udayana di Kediri, Ketua DPRD Kabupaten Tabanan, Camat Kediri, Kapolsek Kediri, Koramil Kediri dan Kepala Desa Abiantuwung. Akhirnya tanggal 4 Juni 2002 diadakan rapat yang dihadiri oleh Pemerintah Kabupaten Tabanan beserta jajarannya. Hasil rapat tersebut berupa Berita Acara yang salah satu isinya adalah Upacara Pitra Yadnya baru dapat diijinkan setelah hari Minggu tanggal 9 Juni 2002. Berdasarkan hasil rapat tersebut, akhirnya upacara pengabenan dilaksanakan pada tanggal 11 Juni 2002.

Selanjutnya diadakan kembali suaturapatuntukmenjagaagarsengketa pelarangan pengabenan tidak terjadi lagi. Rapat tersebut diadakan pada 
tanggal 19 Juni 2002 dan dihadiri oleh Ketua Badan Perwakilan Desa, Kepala Desa Abiantuwung, Camat Kediri beserta para pihak yang bersengketa dimana masing-masing pihak diwakili oleh lima orang warga. Dalam rapat tersebut dibuatlah suatu kesepakatan tentang pemanfaatan Setra Yangapi antara kelompok besar dan kelompok kecil dimana salah satu isi kesepakatan tersebut adalah penggunaan Setra Yangapi bisa dipergunakan secara bersama baik kelompok besar maupun kelompok kecil untuk membakar mayat, menanam (mengubur) dengan syarat harus melapor (mesadok) kepada Bendesa Adat Klaci Kaja dan Bendesa Adat Klaci Kaja wajib mengizinkan.

Sengketa yang ketiga terjadi pelarangan pengabenan warga kelompok kecil yaitu Men Tama dan pada akhirnya pada tanggal 12 Januari 2004 dapat dilaksanakan pengabenan dengan membayar penanjung batu 500 uang kepeng. Hal tersebut jelas sudah menyalahi kesepakatan yang telah dibuat kedua belah pihak.

Sengketa yang keempat terjadi pada tanggal 31 Desember 2004, dimana direncanakan akan dilaksanakan pengabenan I Nyoman Bandri yaitu warga dari kelompok kecil tetapi gagal untuk dilaksanakan mengingat kelompok besar menjaga jalan menuju kuburan dipagar bambu dan di tembok batako. Kelompok Kecil ingin memaksakan untuk dilaksanakannya pengabenan dengan alasan bahwa kuburan tersebut milik bersama hal tersebut berdasarkan kesepakatan yang telah dibuat antara kedua belah pihak yang pada intinya menyebutkan kelompok kecil dapat memanfaatkankuburan dengan terlebih dahulu masadok (memberitahukan) kepada Bendesa Adat, tetapi dibatalkan mengingat adanya pernyataan dari Kapolres Tabanan akan mempidanakan siapa pun yang melanggar melakukan perbuatan melanggar ketertiban umum.

Sebelumnya pada tanggal 30 Desember 2004 sesungguhnya telah diadakan rapat untuk menghindari hal-hal yang tidak diinginkan, dimana rapat tersebut melibatkan kedua belah pihak yang bersengketa. Pada rapat tersebut yang menjadi mediator yaitu seluruh Mupika Kecamatan Kediri, Polres Tabanan diwakilkan Kasat Intel dan Kasat Reskrim serta Kapolsek Kediri. Pada rapat tersebut belum mendapatkan kesepakatan kedua belah pihak yang bersengketa, dimana kelompok kecil tetap ingin melaksanakan pengabenan sedangkan kelompok besar bersikeras melarang untuk melaksanakan pengabenan. Mediasi yang kedua dilakukan Sabtu, 1 Januari 2005 dimana Ketua Majelis Madya Pakraman sebagai mediator. Mediasi tersebut berusaha memberikan solusi untuk dapat menyelesaikan sengketa ini, tetapi mediasi mengalami kegagalan.

Mediasi dilanjutkan pada tanggal 3 Januari 2005, dimana pada saat yang bersamaan Desa Adat Suralaga yang 
merupakan desa yang bersebelahan dengan Banjar Yangapi yang berniat baik meminjamkan tempat setra agar dapat melaksanakan upacara kematian, memberikan informasi bahwa warga desa yang mengizinkan untuk dilaksanakannya pengabenan sebanyak 75 persen. Kelompok kecil pada akhirnya memilih untuk mengkremasi di Mumbul dengan pertimbangan bahwa tidak mau menimbulkan masalah yang baru. Pada tanggal 5 Januari 2005 mayat I Nyoman Badri di kremasi di Krematerium Yasa Setra Mandala Mumbul Jimbaran.

\section{KESIMPULAN}

1. Sengketa upacara kematian merupakan suatu tindakan pelanggaran terhadap hukum nasional yang berhubungan dengan pengaturan tentang kebebasan beragama.

2. Dalam menyelesaikan sengketa pelarangan upacara kematian di Setra Banjar Yangapi pemerintah daerah Kabupaten Tabanan dan jajarannya telah melakukan upaya-upaya mediasi selama beberapa kali telah mencapai beberapa kesepakatan tetapi ternyata hanya kesepakatan semu yang tidak dapat menghentikan timbulnya sengketa pelarangan upacara kematian selama proses pemekaran desa, sehingga salah satu pihak yang bersengketa memilih untuk melakukan upacara kematian tersebut dengan cara mengkremasi.

\section{DAFTAR PUSTAKA}

\section{Buku}

Singgin Wikarman, I Nyoman, 2002, Ngaben Upacara Dari Tingkat

Sederhana Sampai Utama, Paramita, Surabaya.

Surpha, I Wayan, 2006, Seputar Desa Pakraman dan Adat Bali, Pustaka

Bali Post, Denpasar.

Istri Ari Atu Dewi, Anak Agung, 2010, Eksistensi Sanksi Adat Kasepekang Dalam Awig-Awig DalamKaitanDenganPenjatuhan Sanksi Adat Kasepekang di Desa Pakraman, Kerta Patrika Jurnal Ilmiah Fakultas Hukum Universitas Udayana.

Jones, E., 1962, Cureent Trends In Legal Research, (Expert), Journal of Legal Education.

Widnyana, I Made, 1993, Kapita Selekta Hukum Pidana Adat, PT Eresco, Bandung.

Penyelesaian Sengketa (ADR), Indonesia Business Law Center (IBLC) bekerja sama dengan Kantor Hukum Gani Djemat \& Partners, Jakarta.

Sudantra, I Ketut, Windia, Wayan P., dan Dyatmikawati, Putu., 2011, Penuntun Penyuratan AwigAwig, Udayana University Press, Denpasar.

\section{Jurnal}

Adi Susila, I Nyoman, Wirta Griadhi, I Ketut dan Oka Parwata, A.A. Gde, 2013, "Penyelesaian 
Sengketa Adat di Bali Studi

Kasus Sengketa Tanah Setra

Antara Desa Pakraman Cekik

Dengan Desa Pakraman

Gablogan Kecamatan Selemadeg Kabupaten Tabanan", available

URL: ojs.unud.ac.id/index. php/Kerthanegara/article/ download/5293/4050. Diakses tanggal 24 agustus 2017

Dedy Priyanto, I Made,. dkk, 2013, "Penyelesaian Sengketa

Perebutan Tanah Kuburan (Setra) Desa Pakraman Padang Sambian dan Desa Pakraman Kerobokan", available URL: erepo.unud.ac.id/.../ID1_19 8404112008121003200913 11949 9artikel-format-idealpenyeles a ian-sengketaperebutan-tanah-kuburanMicrosoft Word. Diakses tanggal 24 agustus 2017 